\title{
Evaluation of National Libraries' Websites of BRICS Countries: A Webometric Analysis
}

\author{
Krishna Brahma \\ Research Scholar, Mizoram University \\ Mizoram, India \\ krishnabrahma255@gmail.com \\ Manoj Kumar Verma \\ Assistant Professor, Mizoram University \\ Mizoram, India \\ manojdlis@mzu.edu.in
}

\begin{abstract}
The present study evaluates the national libraries'websites of five countries i.e., Brazil, Russia, India, China and South Africa (BRICS). It analyzes the domain \& page authority, domain extensions, internal equity-passing links, external equity-passing links, internal links, external links, total links, followed linking root domains, total linking root domains, just discovered links, linking C blocks, spam score, types of file format and Web Impact Factor of five national libraries' websites. The study explored that the domain (67) \& page Authority (73) of the National Library of China was the highest, the National Library of Russia has secured the highest internal equity-passing links (79884), total equity-passing links (99661) and Total Links (101000), while, the highest external equity-passing links (22354), total external links (22592) and followed linking root domains (1674) was occupied by National Library of China. It also observed that all the selected national libraries are using 100\% HTML, PDF, JPEG, and GIF file formats, followed by PNG, WMA and the lowest was MS-Word, the maximum file formats were used by National Library of Brazil (7). National Library of Russia occupied first place with highest Internal WIF, External WIF and Simple WIF of 1210.36, 326.6 and 1530.3 respectively.
\end{abstract}

Keywords: National Libraries, Webometrics, Websites, Brics Countries, Link Analysis, Web Impact Factor (Wif) etc

Received: 10 July 2018, Revised 23 August 2018, Accepted 31 August 2018

DOI: $10.6025 / \mathrm{ijwa} / 2018 / 10 / 4 / 117-126$

(C) 2018 DLINE. All Rights Reserved

\section{Introduction}

The World Wide Web (WWW) and Information \& Communication Technology (ICT) has transformed the way librarians organize their documents and people access information. Libraries have shifted their role from traditional to an automated 
library. Websites are the primary source of information of any institution/organization and play an important role across the world. With the help of WWW, people are now interconnected, are able to retrieved and share information with each other. The collection development policies and practices have been observed in modern libraries. The National library is a legal repository of the country's property and has got the unique role to play in archiving and dissemination of information to the country people. The sites must be well-organized, informative, easy to navigate, and accessible in both native and foreign languages. National libraries should invest in designing and managing of websites (Walia, \& Gupta, 2012).

The present study is an attempt to analyze the websites of BRICS countries national libraries. Though webometric is an important segment in the field of library and information science. BRICS is an acronym for the grouping of the world's leading emerging economies, namely Brazil, Russia, India, China and South Africa.

\section{Webometric and Web Impact Factor}

The term webometrics was first coined by Almind and Ingwersen (1997) in their seminal paper entitled "informetric analysis of the World Wide Web" A methodological approach to "Webometrics" published in the Journal of Documentation. According to Bjorneborn and Ingwersen, webometrics is the study of the quantitative aspects of the construction and use of information resources, structures and technologies on the web drawing on bibliometric and informetric approaches (Bjorneborn \& Ingwersen, 2004). Webometrics is the new discipline that intends to apply Bibliometrics, Scientometrics, Informetrics and Cybermetric techniques to the processes of scientific communication, which takes place on web in order to know and describe them from a quantitative point of view (Walia \& Kaur, 2008). A Web Impact Factor is a part of methodology in webometric studies. It is the number of webpages in a website receiving links from other websites, divided by the number of webpages published in the site that are accessible to the crawler (Ingwersen, 1998).

\section{BRICS Countries}

The BRICS Leaders' Summit has convened annually with discussions representing spheres of political and socio-economic coordination, in which member countries have identified several business opportunities, economic complementarities, and areas of cooperation. In accordance with acronym B-R-I-C-S, the chairship of the forum is rotated annually among the members. Cooperation among members is established on three levels or tracks of interaction- First are the formal diplomatic engagement between the national governments. Second is engagement through government-affiliated institutions like state-owned enterprises and business councils. The third one is civil society and "people-to-people" engagement. The first BRIC Summit was held in June 2009 in Yekaterinburg, Russia (BRICS, 2018).

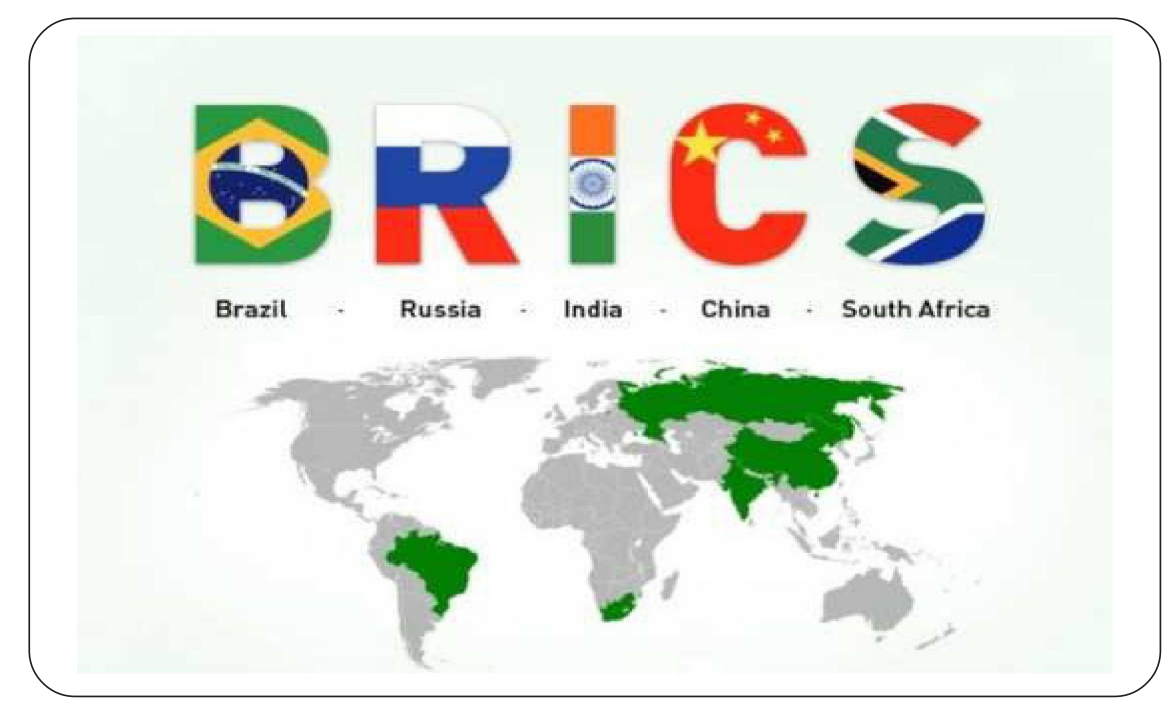

Figure 1. BRICS countries

Source: https://i2.wp.com/www.civilsdaily.com/wp-content/uploads/2016/02/bricsmape1424450584702.jpg?w=521\&h=366 


\section{Literature Review}

Zeinolabedinio et. al. (2006) conducted a study on collaboration analysis of 38 world national library websites via webometric methods and found that the United States of America, Australia and United Kingdom were the popular and most visible national library websites. Jalal et. al. (2010) conducted a webometric study on web presence of selected Asian countries and found that China, Japan and India occupy highest web presence amongst Asian countries based on the total number of effective Internet users. Walia \& Gupta (2012) conducted a study on Web Impact Factor of select national libraries' websites and revealed that among the selected national libraries, websites of national libraries of America, Australia, and Britain were more visible and hosted the more content compare to the websites of India, Namibia, and South Africa. Khan \& Shehzad (2015) examined the national library's websites of Bangladesh, India, Iran, Pakistan and Sri Lanka. The authors have used thirty-five web analysis parameters factors for the evaluation process of the websites and different parameters factors were designed to assess the websites. It found that the website of National Library Board Singapore ranked 1st and National Archives and National Library of Bangladesh ranked at last. Jhamb \& Ruhela (2017) conducted a webometric analysis of the websites of 7 public libraries and found that out of 7 libraries, the website of Central Secretariat library recorded with the highest simple and external web impact factor, RRRLF is the only website having internal and external links, the website of National library leads with the highest number of external and total links and Thanjavur Maharaja Serfoji's Sarasvati Mahal library secured highest number of internal links and Internal WIF. Verma \& Brahma (2017) conducted a study on webometric analysis of national libraries' websites in South Asia and analyzed the number of web pages, link pages and calculates the web impact factor of national libraries' websites and ranks the website as per the WIF. The study visualized that web impact factor of National Library of India was the highest followed by National Library of Sri Lanka and the National Library of Bhutan among the other national libraries websites. Verma \& Brahma (2017) examined the selected library consortium websites in India by analyzing a total number of webpages, domain authority, equity links, internal \& external links and their WIF and observed that e-ShodhSindhu and DeLCon consortiums are the most popular among the selected consortia of India.

\section{Objectives of the study}

The objectives of present study are to:

1. Analyze the URL of BRICS countries national library websites.

2. Find out the domain \& page authority of selected websites

3. Examine the link-equity, just-discovered links and linking root domains of selected websites

5. Find out the internal link and external link pages of selected websites

6. Investigate the type of file formats and to calculate the web impact factor of selected websites taken under study.

\section{The scope of the study}

The present study covers the websites of five national libraries' of BRICS countries and is limited to analysis of web link structure which is shown in Table 1.

\section{Research Methodology}

For the present study, the survey method of research has been applied and the observation technique has been used for collecting data. The websites of national libraries' of BRICS countries were collected and analyzed by using two search enginesOpen Site Explorer (www.opensiteexplorer.org) and Google. Each and every websites were visited to evaluate the file formats used by selected national libraries based on the checklist prepared. Data was collected on 5th July 2018 and were presented in tabular form by using MS Excel.

\section{Method of calculating Web Impact Factor}

Distribution of Data by Internal Web Impact Factor (IWIF) has been calculated by the following formula:

$$
\mathbf{I W I F}=\frac{\text { Total No.of Internal Links }}{\text { Total No.of Webpages }}
$$




\begin{tabular}{|c|c|c|c|c|c|}
\hline Sl. no & BRICS countries & National Library & Website & $\begin{array}{l}\text { Year of } \\
\text { establishment }\end{array}$ & Location/Place \\
\hline 1 & Brazil & National Library of Brazil & https://www.bn.gov.br/ & 1810 & $\begin{array}{l}\text { Rio de Janeiro, } \\
\text { Brazil }\end{array}$ \\
\hline 2 & Russia & National Library of Russia & http://nlr.ru/ & 1795 & $\begin{array}{l}\text { Saint Petersburg, } \\
\text { Brazil }\end{array}$ \\
\hline 3 & India & National Library of India & $\begin{array}{l}\text { http://www.nationallibrar } \\
\text { y.gov.in/ }\end{array}$ & 1953 & $\begin{array}{l}\text { Kolkata, West } \\
\text { Bengal }\end{array}$ \\
\hline 4 & China & National Library of China & http://www.nlc.gov.cn/ & 1909 & Beijing, China \\
\hline 5 & South & $\begin{array}{l}\text { Africa National Library of } \\
\text { South Africa }\end{array}$ & http://www.nlsa.ac.za/ & 1818 & $\begin{array}{l}\text { Cape town and } \\
\text { Petoria }\end{array}$ \\
\hline
\end{tabular}

Table 1. List of BRICS countries National library websites

Distribution of Data by External Web Impact Factor (EWIF) has been calculated by the following formula:

$$
\mathbf{E W I F}=\frac{\text { Total No.of External Links }}{\text { Total No.of Webpages }}
$$

Distribution of Data by Simple Web Impact Factor (SWIF) has been calculated by the following formula:

$$
\mathbf{S W I F}=\frac{\text { Total No.of Links }}{\text { Total No.of Webpages }}
$$

\section{Data Analysis}

Table 2 describes the Domain \& Page Authority of five BRICS countries national libraries' websites. Domain authority is a measure of the power of a domain name. It gives the score (out of 100) of a website to know how well a website ranks on the search engine. In the same way, Page Authority also predicts the score and the potentiality of a specific page how well it ranks in search engine results. It revealed that the Domain Authority of National Library of China was the highest with 67 (23.34\%), followed by Russia with 65 (22.64\%) and Brazil with 57 (19.86\%). Whereas, the Page Authority of National Library of China was also at the top position with 73 (23.24\%), followed by Russia with 66 (21.01\%) and Brazil with 61 (19.42\%).

\begin{tabular}{|l|l|l|l|}
\hline Sl.no. & National Library of BRICS & Domain Authority & Page Authority \\
\hline 1 & Brazil & $57(19.86 \%)$ & $61(19.42 \%)$ \\
\hline 2 & Russia & $65(22.64 \%)$ & $66(21.01 \%)$ \\
\hline 3 & India & $49(17.07 \%)$ & $57(18.15 \%)$ \\
\hline 4 & China & $67(23.34 \%)$ & $73(23.24 \%)$ \\
\hline 5 & South Africa & $49(17.07 \%)$ & $57(18.15 \%)$ \\
\hline & Total & $\mathbf{2 8 7}$ & $\mathbf{3 1 4}$ \\
\hline
\end{tabular}

Table 2. Domain Authority \& Page Authority 
Table 3 classifies the domain extensions of BRICS countries national libraries' websites. It found that '.gov' is used by three countries i.e., Brazil, India and China. While '.ac.' is used by South Africa and all the five countries have its own country code domain.

\begin{tabular}{|c|c|c|c|}
\hline \multirow[b]{2}{*}{ National Library of BRICS } & \multirow[b]{2}{*}{ Uniform Resource Locator (URL) } & \multicolumn{2}{|c|}{ Domain extensions } \\
\hline & & $\begin{array}{l}\text { Genetic Top Level } \\
\text { Domain (gTLD) }\end{array}$ & $\begin{array}{l}\text { Country Code } \\
\text { Domain }\end{array}$ \\
\hline Brazil & https://www.bn.gov.br/ & gov &.$b r$ \\
\hline Russia & http://nlr.ru/ & - &.$r u$ \\
\hline India & http://www.nationallibrary.gov.in/ & gov & in \\
\hline China & http://www.nlc.gov.cn/ & gov &. $\mathrm{cn}$ \\
\hline South Africa & http://www.nlsa.ac.za/ & ac & za \\
\hline
\end{tabular}

Table 3. Domain extensions

Table 4 gives the Internal Equity-Passing Links, External Equity-Passing Links \& Total Equity- Passing Links of BRICS countries national libraries' websites. It explored that National Library of Russia has got highest Internal Equity-Passing Links of 79884 (99.84\%), followed by South Africa with 117 (0.14\%) and Brazil with 5 (0.006\%), whereas India and China have zero passing links which indicate poor status. Based on External Equity-Passing Links, China has the maximum of 22354 (44.28\%), followed by Russia with 19777 (39.17\%) and India with 6263 (12.40\%). Based on Total Equity-Passing Links, Russia secured first place with 99661 (76.34\%), followed by China with 22354 (17.12\%) and India with $22354(17.12 \%)$.

\begin{tabular}{|l|l|l|l|l|}
\hline Sl.no. & National Library of BRICS & $\begin{array}{l}\text { Internal Equity- } \\
\text { Passing Link }\end{array}$ & $\begin{array}{l}\text { External Equity- } \\
\text { Passing Links }\end{array}$ & $\begin{array}{c}\text { Total Equity- } \\
\text { Passing Links }\end{array}$ \\
\hline 1 & Brazil & $5(0.006 \%)$ & $1586(3.14 \%)$ & $1591(1.21 \%)$ \\
\hline 2 & Russia & $79884(99.84 \%)$ & $19777(39.17 \%)$ & $99661(76.34 \%)$ \\
\hline 3 & India & 0 & $6263(12.40 \%)$ & $6263(4.79 \%)$ \\
\hline 4 & China & 0 & $22354(44.28 \%)$ & $22354(17.12 \%)$ \\
\hline 5 & South Africa & $117(0.14 \%)$ & $503(0.99 \%)$ & $670(0.51 \%)$ \\
\hline & Total & $\mathbf{8 0 0 0 6}$ & $\mathbf{5 0 4 8 3}$ & $\mathbf{1 3 0 5 3 9}$ \\
\hline
\end{tabular}

Table 4. Internal Equity-Passing Links, External Equity-Passing Links \& Total Equity-Passing Links

Table 5 indicates the Total Internal Links, Total External Links, Total Links, Followed Linking Root Domains \& Total Linking Root Domains of BRICS countries national libraries' websites. The Total Internal links are the hyperlinks on a webpage to another web page resource such as an image or document, on the same website or domain. Whereas, Total External links are hyperlinks that point at any domain other than the domain the link exists on (source). While Total Links are the total amount of links to a site, that would be all types of links. Linking Root Domains are the number of unique domains linking to specific domain or page. Followed Linking Root Domains is a website that links to you. Total Linking Root Domains are the root domains that link to a page 
ordomain is a measure of trust and can help predict higher ranking potential.

The study found that the value of Total Internal Links of BRICS national libraries is same with that of Internal Equity passing Links, in which National Library of Russia has got highest of 79884 (99.84\%), followed by South Africa with $117(0.14 \%)$ and Brazil with $5(0.006 \%)$. In regard to Total External Links, China occupied the first position with 22592 (42.96\%), followed by Russia with 21556 (40.99\%) and India with 6284 (11.95\%). Russia secured first with the highest Total Links of 101000 (76.42\%), followed by China with 22592 (17.09\%) and India with 6284 (4.75\%). The Followed Linking Root Domains of China was highest with 1674 (53.26\%), followed by Russia with 1041 (33.12\%) and South Africa with 195 (6.20\%). The Total Linking Root Domains of China was once again at the lead with 1755 (52.13\%), followed by Russia with 1147 (34.07\%) and South Africa with 211 (6.26\%).

\begin{tabular}{|l|l|l|l|l|l|l|}
\hline Sl. no. & $\begin{array}{l}\text { National Library } \\
\text { of BRICS }\end{array}$ & $\begin{array}{l}\text { Total Internal } \\
\text { Links }\end{array}$ & $\begin{array}{l}\text { Total External } \\
\text { Links }\end{array}$ & Total Links & $\begin{array}{l}\text { Followed } \\
\text { Linking Root } \\
\text { Domains }\end{array}$ & $\begin{array}{l}\text { Total Linking } \\
\text { Root Domains }\end{array}$ \\
\hline 1 & Brazil & $5(0.006 \%)$ & $1597(3.03 \%)$ & $1602(1.21 \%)$ & $95(3.02 \%)$ & $100(2.97 \%)$ \\
\hline 2 & Russia & $79884(99.84 \%)$ & $21556(40.99 \%)$ & $101000(76.42 \%)$ & $1041(33.12 \%)$ & $1147(34.07 \%)$ \\
\hline 3 & India & 0 & $6284(11.95 \%)$ & $6284(4.75 \%)$ & $138(4.39 \%)$ & $153(4.54 \%)$ \\
\hline 4 & China & 0 & $22592(42.96 \%)$ & $22592(17.09 \%)$ & $1674(53.26 \%)$ & $1755(52.13 \%)$ \\
\hline 5 & South Africa & $117(0.14 \%)$ & $553(1.05 \%)$ & $670(0.50 \%)$ & $195(6.20 \%)$ & $211(6.26 \%)$ \\
\hline & Total & $\mathbf{8 0 0 0 6}$ & $\mathbf{5 2 5 8 2}$ & $\mathbf{1 3 2 1 4 8}$ & $\mathbf{3 1 4 3}$ & $\mathbf{3 3 6 6}$ \\
\hline
\end{tabular}

Table 5. Total Internal Links, Total External Links, Total Links, Followed Linking Root Domains \& Total Linking Root Domains

Table 6 shows the Just-Discovered Links of BRICS countries national libraries' websites with its URL of linking page and date discovered. Just Discovered helps to identify the recently created URLs and links (newest links) which are indexed within a few hours to a day of being published. The table depicts that the National Library of Brazil has got three just discovered links and India with only one, but it doesn't appear in the National Library of Russia, China and South Africa.

Table 7 depicts the Linking C Blocks and Spam score of BRICS countries national libraries' websites. Linking C Blocks refers to the part of IP address that's different. The same class $C$ address means something that has the same third octect in the address. It indicates that the sites are all related to each other and on the same server. The Spam score is an aggregate of 17 different flags. The number of flags indicate the status of website i.e. higher the number of flags on a link, the higher the chance that it's spammy. If a link has 1 to 5 flags, it means website is good and if it exceeds more than 5, it indicates that website has some trouble. Each flag represents a wide range of potential signal ranging from content concerns to low authority metrics. It found that the Linking C Blocks of National Library of China was the highest with 1044, followed by Russia with 729 and South Africa with 173. The spam score of China is highest in number (5/17) and it indicates that the status of the website is not at risk and should continue its maintenance.

Table 8 illustrates the types of file Format supported by BRICS countries national library websites. A file format describes the way data (data structure) is stored in a file. The following table shows the type of file formats used by the national library websites of BRICS countries. The format of the filename is based on the end of its name and that portion of the filename is known as the filename extension. For example, GIF images are identified as .gif, WMA file extension (Windows Media Audio) as .wma, etc. It was cleared from the table that all the BRICS national libraries are using HTML, PDF, JPEG, and GIF 100\%, whereas, 80\% are using PNG, followed by WMA 60\%, and the lowest is using MS-Word $20 \%$ and none of the national library websites is using MS-Excel file format. It also visualized that National Library of Brazil has used maximum file formats i.e., a total of 7, followed by National Library of Russia with 6, National Library of India, China and South Africa each with 5 file formats.

$122 \quad$ International Journal of Web Applications Volume 10 Number 4 December 2018 


\begin{tabular}{|c|l|l|l|}
\hline SI. no. & National Library of BRICS & URL of Linking page & Date Discovered \\
\hline 1 & \multirow{2}{*}{ Brazil } & $\begin{array}{l}\text { https://catracalivre.com.br/sp/agenda/gratis/ } \\
\text { biblioteca-mario-deandrade-e-tema-de- } \\
\text { exposicao-dogrupo-pigmento/ }\end{array}$ & $22-06-18$ \\
\cline { 3 - 4 } & & $\begin{array}{l}\text { https://osmalo.blogspot.com/2018 } \\
\text { /06/bibliotecas-nacionales.html }\end{array}$ & \\
\cline { 3 - 4 } & & https://osmalo.blogspot.com/ & $09-06-18$ \\
\hline 2 & Russia & Zero & $09-06-18$ \\
\hline 3 & India & $\begin{array}{l}\text { https://www.patrika.com/jabalpur } \\
\text {-news/unique-library-of-india-3036382/ }\end{array}$ & Zero \\
\hline 4 & China & Zero & Zero \\
\hline 5 & South Africa & Zero & Zero \\
\hline
\end{tabular}

Table 6. Just discovered Links

\begin{tabular}{|l|l|l|l|}
\hline Sl.no. & National Library of BRICS & Linking C Blocks & Spam score \\
\hline 1 & Brazil & 81 & $0 / 17$ \\
\hline 2 & Russia & 729 & $0 / 17$ \\
\hline 3 & India & 124 & $1 / 17$ \\
\hline 4 & China & 1044 & $5 / 17$ \\
\hline 5 & South Africa & 173 & $2 / 17$ \\
\hline
\end{tabular}

Table 7. Linking C Blocks \& Spam score

\begin{tabular}{|l|l|l|l|l|c|l|l|l|l|c|}
\hline Sl.no. & $\begin{array}{l}\text { National } \\
\text { Library } \\
\text { of } \text { BRICS }\end{array}$ & HTML & PDF & MSExcel & MSWord & JPG/JPEG & PNG & GIF & WMA & $\begin{array}{c}\text { Total } \\
\text { formats } \\
\text { supported }\end{array}$ \\
\hline 1 & Brazil & $\checkmark$ & $\checkmark$ & $\times$ & $\checkmark$ & $\checkmark$ & $\checkmark$ & $\checkmark$ & $\checkmark$ & 7 \\
\hline 2 & Russia & $\checkmark$ & $\checkmark$ & $\times$ & $\times$ & $\checkmark$ & $\checkmark$ & $\checkmark$ & $\checkmark$ & 6 \\
\hline 3 & India & $\checkmark$ & $\checkmark$ & $\times$ & $\times$ & $\checkmark$ & $\checkmark$ & $\checkmark$ & $\times$ & 5 \\
\hline 4 & China & $\checkmark$ & $\checkmark$ & $\times$ & $\times$ & $\checkmark$ & $\checkmark$ & $\checkmark$ & $\times$ & 5 \\
\hline 5 & South Africa & $\checkmark$ & $\checkmark$ & $\times$ & $\times$ & $\checkmark$ & $\times$ & $\checkmark$ & $\checkmark$ & 5 \\
\hline & Percentage & $\mathbf{1 0 0 \%}$ & $\mathbf{1 0 0 \%}$ & $\mathbf{0}$ & $\mathbf{2 0 \%}$ & $\mathbf{1 0 0 \%}$ & $\mathbf{8 0 \%}$ & $\mathbf{1 0 0 \%}$ & $\mathbf{6 0 \%}$ & \\
\hline
\end{tabular}

Table 8. Types of File Format supported by BRICS countries National library websites 
Table 9 and 9.1 depicts the search engine performance in the analysis of BRICS countries national library websites and shows the differences in performance of search result by using same search expression without gap after command and with the gap after a command. In Table no. 9, the study found that search expression with the gap is having more number of hits in comparison to search expression without the gap. The command site:URL means the number of all the pages inside the URL. It gives huge variation in data for the same search expression without gap and with gap. Same with Table no. 9.1, the command link:URL (without gap) and link: URL (with gap) was used for search result. Link:URL means total number of webpages which have links to given URL.

\begin{tabular}{|l|l|l|l|}
\hline Search Expression (Without gap) & No. of Hits & Search Expression (With gap) & No. of Hits \\
\hline site:www.bn.gov.br/ & 14,400 & site: www.bn.gov.br/ & $3,45,00,000$ \\
\hline site:www.nlr.ru/ & 1,350 & site: www.nlr.ru/ & $26,00,000$ \\
\hline site:www.nationallibrary.gov.in/ & 975 & site:www.nationallibrary.gov.in/ & $5,35,00,000$ \\
\hline site:www.nlc.gov.cn/ & 17,200 & site: www.nlc.gov.cn/ & $56,60,000$ \\
\hline site:www.nlsa.ac.za/ & 3,440 & site: www.nlsa.ac.za/ & 60,000 \\
\hline
\end{tabular}

Table 9. Search Engine Performance in data collection

(With site command site:URL and site: URL)

Data collection Date \& Time: 09.07.2018 between 12:00 pm to 12:08 pm

\begin{tabular}{|l|l|l|l|}
\hline Search Expression (Without gap) & No. of Hits & Search Expression (With gap) & No. of Hits \\
\hline link:www.bn.gov.br/ & $46,40,000$ & link: www.bn.gov.br/ & $19,20,00,000$ \\
\hline link:www.nlr.ru/ & $2,51,000$ & link: www.nlr.ru/ & $28,40,000$ \\
\hline link:www.nationallibrary.gov.in/ & $3,98,00,000$ & link:www.nationallibrary.gov.in/ & $5,45,00,000$ \\
\hline link:www.nlc.gov.cn/ & $1,42,000$ & link: www.nlc.gov.cn/ & $59,70,000$ \\
\hline link:www.nlsa.ac.za/ & 12,900 & link: www.nlsa.ac.za/ & 55,300 \\
\hline
\end{tabular}

Table 9.1. Search Engine Performance in data collection (With link command link:URL and link: URL)

Data collection Date \& Time: 09.07.2018 between 12:00 pm to 12:08 pm

Table 10 gives the Web Impact Factor (WIF) of BRICS countries national library websites which include Internal WIF, External WIF and Simple WIF. It was found that the National Library of Russia occupied first place with highest Internal WIF, External WIF and Simple WIF of 1210.36, 326.6 and 1530.3 respectively. It also observed that the Internal WIF of other four (Brazil, India, China and South Africa) national libraries' need to improve its link structure for better web presence. The National Library of China recorded second highest External WIF of 309.47, followed by India with 110.24 EWIF and the other two libraries (Brazil and South Africa) have less External WIF. After Russia, National Library of China stood the second position with 110.24 SWIF and India with 110.24 SWIF at third place.

\section{Major findings of the study are}

1. The National Library of China has the highest Domain \& Page Authority of 67 and 73 respectively, followed by Russia (DA= $65 \& \mathrm{PA}=66)$ and Brazil $(\mathrm{DA}=57 \& \mathrm{PA}=61)$.

2. The National Library of Russia has secured highest Internal Equity-Passing Links and Total Equity-Passing Links of 79884 


\begin{tabular}{|l|l|l|l|l|}
\hline Sl.no. & National Library of BRICS & IWIF & EWIF & SWIF \\
\hline 1 & Brazil & 0.08 & 6.18 & 26.26 \\
\hline 2 & Russia & 1210.36 & 326.6 & 1530.3 \\
\hline 3 & India & 0 & 110.24 & 110.24 \\
\hline 4 & China & 0 & 309.47 & 309.47 \\
\hline 5 & South Africa & 2.05 & 9.7 & 11.75 \\
\hline
\end{tabular}

Table 10. Web Impact Factor

and 99661 respectively, whereas, the External Equity-Passing Links of National Library of China was highest with 22354, while India and China have zero passing links which indicate poor status.

3. National Library of Russia has got highest Internal \& Total Links of 79884 \& 101000 respectively. Based on Total External Links \& Followed Linking Root Domains, China occupied first position with 22592 \& 1674 respectively.

4. The National Library of Brazil has got three just discovered links and India with only one and other three websites of Russia, China and South Africa do not have any newest links.

5. The spam score of the National Library of China was maximum in number i.e., 5/17 which means the website is running well.

6. The National Library of Russia occupied first place with highest Internal WIF, External WIF and Simple WIF of 1210.36, 326.6 and 1530.3 respectively, whereas, the National Library of China occupied second place with External WIF of 309.47 and India third with 110.24 EWIF. And the National Library of China occupied second position with 110.24 SWIF and India with 110.24 SWIF at third place.

\section{Discussion and Conclusion}

The paper concentrates at knowing the present status of national libraries' websites of BRICS countries. It is an association formed by countries in four continents: Brazil in Americas, Russia in Europe, India and China in Asia and South Africa in Africa. The authors discovered that the score of domain and page authority of the undertaken websites seems good, the internal equitypassing links and total internal links of Brazil, India and China was found very poor and the websites should concentrate on building its links. It visualized that Web Impact Factor of National Library of Russia secured at first place with the highest IWIF, EWIF and SWIF. National Library of China has second highest EWIF and SWIF, but with zero IWIF, followed by National Library of India with third highest EWIF and IWIF, but IWIF was also found zero. It concludes by revealing that the Internal WIF of all the four national libraries was very low and should be lifted up. Also, it has been noticed that the WIF of National Library of South Africa was the lowest among the five countries. There is a huge difference in the web presence of Brazil and South Africa. It is suggested that national libraries need to be more meticulous when library resources are provided worldwide. The library websites give the image of the standard of a library. Hence, the collaboration among these BRICS countries should stay strong not only by maintaining governmental relations but also by having good interconnection among national libraries websites for online sharing of resources among BRICS and to make productive use of the resources by the concerned users.

\section{References}

[1] Almind, T.C., Ingwersen, P. (1997). Informetric analyses on the World Wide Web: methodological approaches to webometrics. Journal of Documentation, 53 (4) 404-426. Available at: https://doi.org/10.1108/EUM0000000007205.

[2] Bjorneborn, L., Ingwersen, P. (2004). Towards a basic framework for webometrics. Journal of the American Society for Information Science and Technology, 55 (14) 1216-1227. Available at: https://doi.org/10.1002/asi.20077.

[3] Ingwersen, P. (1998). The calculation of web impact factors. Journal of Documentation, 54 (2) 236-243. Available at: http:// citeseerx.ist.psu.edu/viewdoc/download?doi=10.1.1.113.6384\&rep=rep1\&type=pdf. 
[4] Jalal, S. K., Biswas, S.C., Mukhopadhyay P. (2010). Web presence of selected Asian countries: A webometric study. Collnet Journal of Scientometrics and Information Management, 4 (2) 1-12.

[5] Jhamb, G. \& Ruhela, A. (2017). A Webometric study of the websites of public libraries. International Journal of Library and Information Studies, 7 (4) 83-89.

[6] Khan, N. M., Shehzad F. (2015). The evaluation of national library's websites of Bangladesh, India, Iran, Pakistan and Sri Lanka. Pakistan Library \& Information Science Journal 46 (4) 4-11.

[7] Verma, M. K., Brahma, K. (2017). A webometric analysis of national libraries' websites in South Asia, Annals of Library and Information Studies, 64 (2) 116-124.

[8] Verma, M.K., Brahma, K. 2017. Webometric analysis of selected library consortium websites of india: an evaluative study. In: Proceedings of the $11^{\text {th }}$ International CALIBER (p. 328-341). Tamil Nadu: INFLIBNET.

[9] Walia, P. K., Kaur, P. (2008). Webometric analysis of library associations' websites of India. IASLIC Bulletin, 53 (3) 131-143.

[10] Zeinolabedinio, M. H., Maktabifard, L., Osareh, F. (2006). Collaboration analysis of world national library websites via webometric methods. In: International Workshop on Webometrics, Informetrics and Scientometrics \& Seventh COLLNET Meeting. France.

[11] BRICS, 2018. Retrieved from: http://www.brics2018.org.za/. 